IN PRACTICE

\title{
Acceptability of human papillomavirus self testing in female adolescents
}

\author{
J A Kahn, D I Bernstein, S L Rosenthal, B Huang, L M Kollar, J L Colyer, A M Tissot, P A Hillard, \\ D Witte, P Groen, G B Slap
}

Sex Transm Infect 2005;81:408-414. doi: 10.1136/sti.2004.012047

\begin{abstract}
See end of article for authors' affiliations

........

Correspondence to: Jessica A Kahn, MD, MPH, Division of Adolescent Medicine, MLC 4000 Cincinnati Children's Hospital Medical Center, 3333 Burnet Avenue, Cincinnati, OH 45229 USA; jessica.kahn@cchmc. org
\end{abstract}

Accepted for publication 21 December 2004
Objectives: To develop scales assessing acceptability of human papillomavirus (HPV) testing in adolescents, to compare acceptability of self to clinician testing, and to identify adolescent characteristics associated with acceptability.

Methods: Female adolescents 14-21 years of age attending a hospital based teen health centre self collected vaginal samples and a clinician, using a speculum, collected cervicovaginal samples for HPV DNA. Acceptability of and preferences for self and clinician testing were assessed at baseline and 2 week visits.

Results: The mean age of the 121 participants was 17.8 years and $82 \%$ were black. The acceptability scales demonstrated good internal consistency, reliability, test-retest reliability, and factorial validity. Scores were significantly lower for self testing than clinician testing on the acceptability scale and three subscales measuring trust of the test result, confidence in one's ability to collect a specimen, and perceived effects of testing $(p<0.01)$. Of those who reported a preference, $73 \%$ preferred clinician to self testing. Acceptability scores for both self and clinician testing increased significantly pre-examination to postexamination $(p<0.01)$. Multivariable analyses demonstrated that race was independently associated with pre-examination and post-examination acceptability of self testing, and that sexual behaviours and gynaecological experiences were associated with specific acceptability subscales.

Conclusions: This sample of adolescents found clinician testing for HPV to be more acceptable than self testing and preferred clinician to self testing. If self testing for HPV is offered in the future, clinicians should not assume that adolescent patients will prefer self testing. Instead, they should educate adolescents about available testing options and discuss any concerns regarding self collection technique or accuracy of test results.
$\mathrm{H}$ man papillomavirus (HPV) infection is highly prevalent in sexually active adolescents and young adults, ${ }^{12}$ and although most infections resolve spontaneously, persistent infection with high risk HPV types may lead to cervical carcinoma. ${ }^{3}$ Cervical cancer prevention strategies, which rely on periodic Papanicolaou (Pap) testing and follow up of abnormal results, are limited by the low sensitivity of Pap tests for detection of severe dysplasia and the high costs associated with screening and follow up procedures such as colposcopy. ${ }^{5}$ Pap testing in adolescents is particularly problematic because the vast majority of cytological abnormalities in adolescents regress or do not represent cervical intraepithelial neoplasia (CIN) $2 / 3$ or carcinoma in situ. ${ }^{78}$ Thus, mildly abnormal cervical cytology results may lead to diagnostic procedures that are unnecessary and may impact adversely on future adherence to Pap screening or colposcopy recommendations.

In light of the limitations of Pap testing and the importance of HPV infection in the development of cervical cancer, investigators have explored whether HPV DNA testing should be incorporated into cervical cancer screening programmes. Based on a number of studies demonstrating the sensitivity of high risk HPV DNA for the detection of CIN $2 / 3,{ }^{9-11}$ recent guidelines state that HPV DNA testing may be used as an adjunct to Pap testing in women with atypical squamous cells of undetermined significance (ASCUS) and as an alternative to Pap testing in the surveillance of selected women with CIN. ${ }^{12}{ }^{13}$ Samples for HPV DNA may be collected using a clinician or patient collected vaginal swab, eliminating the need for a speculum examination in some circumstances. ${ }^{14-16}$ Self collection may be advantageous for women who find the speculum examination uncomfortable or in healthcare settings in which providers do not have the resources or the expertise to perform a speculum examination. It also may facilitate the collection of HPV DNA specimens in research protocols that examine HPV epidemiology or HPV vaccine efficacy. Studies suggest that adult women find self collected samples for HPV DNA more acceptable than clinician collected samples. ${ }^{14}{ }^{17-19}$ Adolescents similarly find self testing for sexually transmitted infections (STIs) other than HPV, such as chlamydia and gonorrhoea, to be acceptable and report that self testing is more private and less embarrassing than clinician testing. ${ }^{20-22}$ It is unclear whether adolescents will perceive self testing for HPV to be acceptable and which adolescent characteristics will influence acceptability.

Therefore, the aims of this study were as follows: (1) to develop scales to measure acceptability of self and clinician testing for HPV DNA, (2) to compare acceptability of self to clinician collected swabs, (3) to compare preferences for self $v$ clinician testing, and (4) to examine whether acceptability and preferences for testing differ by sociodemographic factors, behavioural factors, and gynaecological history. Our hypotheses were that adolescents would find self testing

\footnotetext{
Abbreviations: ANOVA, analysis of variance; ASCUS, atypical squamous cells of undetermined significance; CIN, cervical intraepithelial neoplasia; GFI, goodness of fit index; HPV, human papillomavirus; Pap, Papanicolaou; RMR, root mean square residual; $\mathrm{STI}$, sexually transmitted infections
} 
more acceptable than clinician testing, that adolescents would prefer self to clinician testing, and that history of STI and tampon use would be associated with acceptability of self testing.

\section{METHODS}

Participants

A convenience sample of participants was recruited from an urban, hospital based teen health centre between July 2002 and January 2003 for a study examining the accuracy and acceptability of HPV self $v$ clinician testing. ${ }^{15}$ The protocol was approved by the hospital's institutional review board. Adolescents were eligible if they were female, 14-21 years of age, and had had sexual intercourse. Exclusion criteria included history of cervical dysplasia documented by colposcopically directed biopsy, current pregnancy, or a mental or physical health issue that would preclude the ability to assent or to participate meaningfully in the study.

\section{Study procedures}

At the baseline visit, participants completed the first of three surveys (pre-examination survey) assessing acceptability of self and clinician testing; the research coordinator then conducted a standardised educational protocol about HPV and Pap tests. Participants self obtained vaginal specimens for HPV DNA using a BBL Culture Swab, then one of the clinicians (JK or LK) inserted a speculum and obtained an endocervical/ectodervical sample for HPV DNA and a specimen for liquid based cervical cytology. After testing, subjects were given the second survey (post-examination survey), and returned 2 weeks later to complete the third survey (2 week follow up survey) before receiving test results.

The first survey included items assessing sociodemographic characteristics, gynaecological and medical history, knowledge about HPV, and acceptability of self and clinician testing. The second and third surveys only assessed acceptability. Acceptability was measured using two 13 item scales assessing acceptability of self and clinician testing for HPV DNA which were developed based on previous literature. ${ }^{18} 1923$ Responses were on a three point scale (scored 1$3)$, with higher scores indicating higher acceptability. One additional item measured preference for self testing or clinician testing.

\section{Analyses}

Statistical analyses were performed using SAS version 8.2. Content validity of scales measuring acceptability and knowledge were assured by expert review and adaptation of items from previous surveys. ${ }^{23}{ }^{24}$ Test-retest reliability (temporal stability reliability) was assessed by comparing postexamination survey scale scores at the baseline visit with 2 week follow up survey scale scores, using an intraclass correlation coefficient. Cronbach's alpha was calculated to assess internal consistency reliability. In order to assess construct validity, the mean scores of the scales measuring acceptability of self testing were compared for those who reported a preference for self testing, clinician testing, or neither, using a one way analysis of variance (ANOVA) procedure. Factor analysis was performed to explore the factorial structure of the acceptability scales. Exploratory factor analysis was performed using principal component analysis with orthogonal rotation. Factor loadings $>0.40$ and a scree plot were used as criteria for determining which items loaded on a factor. ${ }^{25}{ }^{26}$ First order confirmatory factor analysis was performed to assess the fit of the model to the factors identified in the exploratory analysis. Second order confirmatory factor analysis ${ }^{26}$ was performed to measure the fit of the identified factors to a single underlying factor (that is, acceptability)..$^{27-29}$
Differences between self and clinician testing acceptability and differences between pre-examination and post-examination acceptability were assessed using paired $t$ tests and Wilcoxon signed rank tests. The study sample of 121 subjects had $96 \%$ power to detect an effect size of 0.352 - that is, a difference between self and clinician testing acceptability scale scores of 1.76 (possible range 13-39). Associations between participant characteristics and acceptability of self testing (pre-testing and post-testing) were examined in univariate analyses. Participant characteristics included sociodemographic characteristics (age, race, grade level, and insurance status), sexual behaviours (number of lifetime sexual partners, sexual partners in the past 6 months, contraceptive use at last sexual intercourse, and condom use at last sexual intercourse), gynaecological history (previous use of tampons, history of STI, history of abnormal cervical cytology), and knowledge about HPV. Analysis of variance was used to compare interval scale variables between groups, Wilcoxon rank sum tests were used to compare ordinal variables between groups, and $\chi^{2}$ tests were used for pairs of nominal scaled variables.

Those participant characteristics associated in univariate analyses at $\mathrm{p}<0.10$ with acceptability of self testing (preexamination and post-examination) were entered into separate linear regression models to identify those variables independently associated with acceptability of self testing. The outcome variables for these models included the total acceptability scale score and the subscale scores. A forward stepwise method was used, with variables grouped into sociodemographic, behavioural, and gynaecological categories.

\section{RESULTS}

Of the 162 eligible patients who were approached initially, 16 declined participation because of concerns about a pelvic examination, insufficient time, or lack of interest. Of the 146 $(90 \%)$ who agreed to participate, $121(83 \%)$ completed the consent process and the first study visit and 116 (96\%) returned for the second study visit. Those who completed the first study visit $(n=121)$ did not differ from those who did not $(n=41)$ in terms of age $(p=0.69)$, race $(p=0.45)$, or number of lifetime sexual partners $(p=0.16)$.

The mean age of participants was 17.8 (SD 1.9) years, and self reported race was as follows: 98 (82\%) black, 15 (13\%) white, and seven $(6 \%)$ other. One participant reported Latino ethnicity. Most patients (74\%) had Medicaid health insurance. Mean age of first sexual intercourse was 14.3 (SD 2.0) years, mean number of lifetime sexual partners was 5.7 (SD 5.9), 69 (58\%) reported having ever used a tampon, $32(26 \%)$ reported a history of an abnormal Pap test, and seven (6\%) reported a history of genital warts. Baseline testing demonstrated that $51 \%$ were HPV positive and $23 \%$ had abnormal cervical cytology.

The mean values for responses to almost all individual items assessing acceptability fell between 2 and 3, indicating that participants generally found self and clinician testing to be acceptable. Values for individual items and acceptability scale scores are shown in table 1 . Temporal stability reliability was good as measured by an intraclass correlation coefficient of 0.82 (comparing the post-examination and follow up self testing acceptability scale scores). Internal consistency reliability was also very good as measured by Cronbach's alpha (range 0.84-0.87 for scales measuring self testing acceptability). ${ }^{25}$ In all three surveys, those who preferred self testing had significantly higher mean self testing acceptability scale scores than those who preferred clinician testing (pre-examination survey scores: $32.3 v 29.8, \mathrm{p}=0.002$ ), supporting construct validity. 
Table 1 Acceptability of self testing and clinician testing, pre-examination and post-examination

\begin{tabular}{|c|c|c|c|c|}
\hline & \multicolumn{2}{|l|}{ Acceptability of self testing } & \multicolumn{2}{|c|}{ Acceptability of clinician testing } \\
\hline & \multicolumn{2}{|l|}{ Mean $(95 \% \mathrm{Cl})$} & \multicolumn{2}{|l|}{ Mean $(95 \% \mathrm{Cl})$} \\
\hline & Pre-examination & Post-examination & Pre-examination & Post-examination \\
\hline 1 Believe test result is correct & $2.19(2.07$ to 2.31$)$ & 2.35 (2.24 to 2.46$)$ & 2.76 (2.68 to 2.84$)$ & 2.87 (2.81 to 2.93 ) \\
\hline 2 Trust the test result & $2.53(2.42$ to 2.64$)$ & $2.42(2.30$ to 2.54$)$ & $2.87(2.81$ to 2.93$)$ & 2.86 (2.79 to 2.93 ) \\
\hline 3 Swab is not hard to insert & $2.47(2.35$ to 2.59$)$ & $2.53(2.41$ to 2.65$)$ & $2.73(2.63$ to 2.83$)$ & 2.86 (2.79 to 2.93 ) \\
\hline 4 Not hard to collect the specimen correctly & $2.21(2.08$ to 2.34$)$ & $2.45(2.33$ to 2.57$)$ & $2.85(2.79$ to 2.91$)$ & $2.83(2.75$ to 2.91$)$ \\
\hline 5 Sure that collected specimen from the right place & 1.95 (1.82 to 2.08$)$ & $2.40(2.27$ to 2.53$)$ & $2.79(2.71$ to 2.87$)$ & 2.89 (2.83 to 2.95 ) \\
\hline 6 Not bothered by procedure & 2.40 (2.28 to 2.52$)$ & $2.50(2.39$ to 2.61$)$ & 2.35 (2.24 to 2.46$)$ & $2.59(2.48$ to 2.70$)$ \\
\hline 7 Procedure is not uncomfortable & 2.10 (1.98 to 2.22$)$ & $2.30(2.17$ to 2.43$)$ & 2.20 (2.07 to 2.33 ) & $2.47(2.35$ to 2.59$)$ \\
\hline 8 Procedure is not painful & $2.58(2.47$ to 2.69$)$ & $2.75(2.65$ to 2.85$)$ & $2.63(2.53$ to 2.73$)$ & 2.75 (2.66 to 2.84$)$ \\
\hline 9 Procedure is not unpleasant & $2.23(2.12$ to 2.34$)$ & $2.40(2.29$ to 2.51$)$ & $2.28(2.16$ to 2.40$)$ & $2.57(2.46$ to 2.68$)$ \\
\hline 10 Procedure is not embarrassi & $2.58(2.46$ to 2.70$)$ & 2.75 (2.65 to 2.85$)$ & $2.48(2.37$ to 2.59$)$ & 2.65 (2.54 to 2.76$)$ \\
\hline 11 Would feel in control of one's health after testing & $2.43(2.31$ to 2.55$)$ & 2.48 (2.37 to 2.59$)$ & $2.60(2.50$ to 2.70$)$ & 2.65 (2.56 to 2.74$)$ \\
\hline $\begin{array}{l}12 \text { Believe testing is a good thing to do for one's } \\
\text { health }\end{array}$ & 2.71 (2.61 to 2.81$)$ & 2.75 (2.66 to 2.84 ) & 2.95 (2.91 to 2.99 ) & 2.91 (2.85 to 2.97 ) \\
\hline $\begin{array}{l}13 \text { Would recommend testing to a friend } \\
\text { Total acceptability score }\end{array}$ & $\begin{array}{l}2.60(2.49 \text { to } 2.71) \\
30.98 \text { (30.08 to } 31.87)\end{array}$ & $\begin{array}{l}2.67(2.56 \text { to } 2.78) \\
32.74(31.85 \text { to } 33.63)\end{array}$ & $\begin{array}{l}2.77(2.68 \text { to } 2.86) \\
34.23(33.63 \text { to } 34.84)\end{array}$ & $\begin{array}{l}2.88(2.81 \text { to } 2.95) \\
35.80(35.17 \text { to } 36.43)\end{array}$ \\
\hline
\end{tabular}

Exploratory factor analysis with review of the scree plot identified four factors underlying the acceptability scale items: trust of test result, confidence in one's ability to collect the specimen correctly, comfort of procedure, and perceived effects of testing. The model tested in confirmatory factor analysis is shown in figure 1. The squared multiple correlations $\left(\mathrm{R}^{2}\right)$ of the 13 items that were accounted for by the four factors F1 to F4 (that is, the variance in each item explained by the corresponding factor) ranged from 0.20 to 0.69 . The $\mathrm{R}^{2}$ of the four factors that were accounted for by acceptability (that is, the variance in each factor explained by the overall construct of acceptability) ranged from 0.39-0.69. Goodness of fit measures for the second order model, which tests the hypothesis that the four factor model that we identified supports one underlying factor (acceptability), were adequate: goodness of fit index (GFI) 0.89 , adjusted GFI 0.82, and root mean square residual (RMR) 0.09 (preexamination scale) and GFI 0.86, AGFI 0.77, and RMR 0.08 (post-examination scale).

In the pre- examination and post-examination surveys, overall acceptability of clinician testing was significantly higher than self testing (table 2). The magnitude of the difference between attitudes about clinician and self testing was greatest for trust of test result and confidence in ability to collect the specimen. In addition, post-examination acceptability was higher than pre-examination acceptability, both for self and clinician testing. Before the examination the majority of participants preferred clinician testing to self testing (fig 2), and after the examination the proportion who preferred self testing increased but not significantly. Of those who reported a preference after the examination, 73\% preferred clinician testing and $27 \%$ self testing.

Sociodemographic, behavioural, and gynaecological variables associated in univariate analyses with the total self testing acceptability scale score at $\mathrm{p}<0.10$, measured at the pre-examination visit, included race $(p=0.013)$, insurance status $(p=0.092)$, and history of an STI $(p=0.020)$. The only variable associated with the total self testing acceptability scale score at the post-examination visit was race $(p=0.031)$. Results of the multivariable analyses are shown in table 3. Compared to those participants who reported race other than white or black, white participants found self testing more acceptable pre-examination, while both black and white participants found self testing more acceptable post-examination. History of an STI, history of an abnormal Pap test, previous tampon use, and number of lifetime sexual partners were positively associated with specific acceptability subscales. Although number of sexual partners in the past

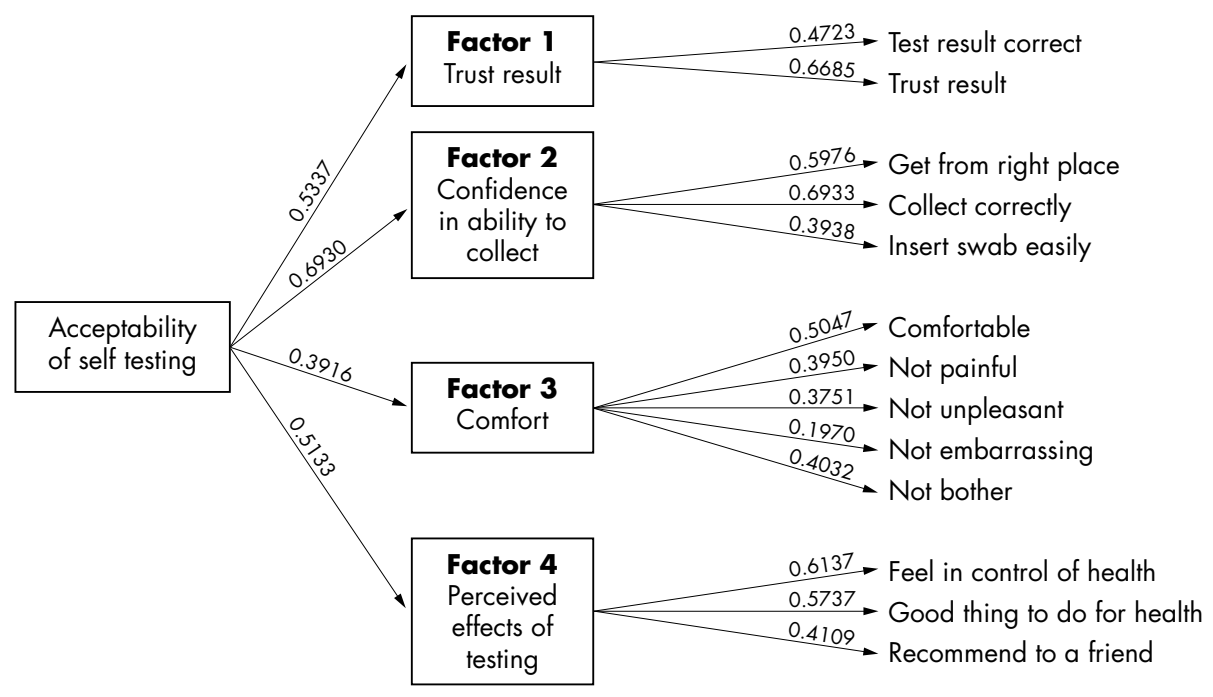

Figure 1 Confirmatory factor analysis, pre-examination survey of self testing acceptability. Squared multiple correlations $\left(R^{2}\right)$ are indicated. The $R^{2}$ of the 13 items on the right side of the figure represent the variance in each item explained by the corresponding factor (F1-F4). The $\mathrm{R}^{2}$ of the four factors on the left side of the diagram represent the variance in each factor explained by the overall construct of acceptability. 


\begin{tabular}{|c|c|c|c|c|}
\hline \multirow[b]{3}{*}{ Subscales and individual items } & \multirow{2}{*}{\multicolumn{2}{|c|}{$\begin{array}{l}\text { Clinician testing } v \text { self testing } \\
\text { Difference in mean score }(95 \% \mathrm{Cl})\end{array}$}} & \multirow{2}{*}{\multicolumn{2}{|c|}{$\begin{array}{l}\text { Pre-examination } v \text { post-examination } \\
\text { Difference in mean score }(95 \% \mathrm{Cl})\end{array}$}} \\
\hline & & & & \\
\hline & Pre-examination & Post-examination & Self testing & Clinician testing \\
\hline \multirow[t]{3}{*}{ Trust o } & $0.91(0.68 \text { to } 1.14)^{* \star *}$ & 0.960 .74 to 1.18$)^{* * *}$ & $0.04(0.16$ to .025$)$ & $0.11(0.004 \text { to } 0.22)^{*}$ \\
\hline & $0.57(0.43 \text { to } 0.71)^{* \star *}$ & $0.53(0.41 \text { to } 0.64)^{* * *}$ & $0.15(0.02 \text { to } 0.28)^{*}$ & $0.12(0.04 \text { to } 0.19)^{* *}$ \\
\hline & $0.34(0.23 \text { to } 0.45)^{\star \star *}$ & $0.43(0.31 \text { to } 0.56)^{\star * \star *}$ & $-0.11(-0.22$ to .004$)$ & $-0.01(-0.07$ to 0.06$)$ \\
\hline \multirow{4}{*}{$\begin{array}{l}\text { Confidence in ability to collect } \\
\text { Swab not hard to insert } \\
\text { Not hard to collect specimen correctly } \\
\text { Sure that collected from right place }\end{array}$} & $1.74(1.4 \text { to } 2.1)^{\star \star \star}$ & $1.20(0.85 \text { to } 1.56)^{* \star *}$ & $0.73(0.35 \text { to } 1.11)^{* *}$ & $0.19(-0.03$ to 0.42$)$ \\
\hline & $0.26(0.12 \text { to } 0.40)^{* *}$ & $0.33(0.20 \text { to } 0.46)^{* \star *}$ & 0.07 (0.09 to 0.23 ) & $0.14(0.01$ to 0.26$)$ \\
\hline & $0.64(0.51 \text { to } 0.77)^{\star \star \star *}$ & $0.38(0.25 \text { to } 0.51)^{\star \star \star *}$ & $0.22(0.06 \text { to } 0.38)^{*}$ & $-0.03(-0.12$ to 0.07$)$ \\
\hline & 0.84 (0.69 to 0.99$)^{\star \star * *}$ & $0.49(0.35 \text { to } 0.64)^{\star * *}$ & $0.44(0.28 \text { to } 0.60)^{* * *}$ & $0.08(-0.009$ to 0.18$)$ \\
\hline Comfort of procedure & $0.05(-0.45$ to 0.35$)$ & $0.36(0.09$ to 0.81$)$ & $0.79(0.38 \text { to } 1.20)^{* *}$ & $1.11(0.73 \text { to } 1.49)^{* \star *}$ \\
\hline \multirow{2}{*}{$\begin{array}{l}\text { Not bothered by procedure } \\
\text { Procedure not uncomfortable }\end{array}$} & $-0.05(-0.09$ to 0.19$)$ & $0.09(0.02$ to 0.21$)$ & 0.09 (0.04 to 0.23 ) & $0.24(0.10 \text { to } 0.37)^{* *}$ \\
\hline & $0.10(0.04$ to 0.24$)$ & $0.18(0.04 \text { to } 0.32)^{* * \star}$ & $0.19(0.04 \text { to } 0.30)^{*}$ & $0.27(0.13 \text { to } 0.41)^{* *}$ \\
\hline & $0.05(-0.06$ to 0.16$)$ & $0.01(-0.12$ to 0.10$)$ & $0.16(0.04 \text { to } 0.28)^{*}$ & $0.13(0.01 \text { to } 0.24)^{*}$ \\
\hline $\begin{array}{l}\text { Procedure not painful } \\
\text { Procedure not unpleasant }\end{array}$ & $0.04(-0.04$ to 0.54$)$ & $0.17(0.04 \text { to } 0.32)^{\star \star \star *}$ & $0.17(0.03 \text { to } 0.31)^{*}$ & $0.30(0.17 \text { to } 0.42)^{* \star *}$ \\
\hline & $-0.09(-0.03$ to 0.22$)$ & $-0.09(-0.021$ to 0.21$)$ & $0.18(0.08 \text { to } 0.27)^{* *}$ & $0.18(0.06 \text { to } 0.29)^{* *}$ \\
\hline & $0.56(0.25 \text { to } 0.86)^{* *}$ & $0.54(0.24 \text { to } 0.84)^{* *}$ & 0.15 (0.07 to 0.38$)$ & $0.14(0.005$ to 0.29$)$ \\
\hline $\begin{array}{l}\text { Perceived effects of testing } \\
\text { Would feel in control of on }\end{array}$ & $0.16(0.01 \text { to } 0.31)^{*}$ & $0.17(0.02 \text { to } 0.32)^{\star * \star}$ & 0.05 (0.07 to 0.17 ) & $0.07(-0.03$ to 0.17$)$ \\
\hline Testing is a good thing to do for health & $0.23(0.13 \text { to } 0.34)^{\star * *}$ & $0.16(0.04 \text { to } 0.28)^{* * *}$ & $0.03(0.06$ to 0.13$)$ & $-0.04(-0.11$ to 0.02$)$ \\
\hline Would recommend testing to a friend & $0.17(0.05 \text { to } 0.29)^{*}$ & $0.21(0.11 \text { to } 0.32)^{* * *}$ & $0.07(0.03$ to 0.17$)$ & $0.12(0.04 \text { to } 0.19)^{\star *}$ \\
\hline Total acceptability scale score & $3.26(2.37 \text { to } 4.14)^{\star * *}$ & $3.06(2.09 \text { to } 4.03)^{* * *}$ & $1.71(0.83 \text { to } 2.59)^{* *}$ & $1.56(0.99 \text { to } 2.12)^{\star * *}$ \\
\hline
\end{tabular}

6 months was associated with subscales measuring acceptability, higher number of partners was not linked to higher acceptability.

\section{DISCUSSION}

Participants in this study found clinician testing for HPV to be more acceptable than self testing and preferred clinician testing to self testing. While race was the only variable independently associated with overall acceptability, other variables related to sexual experience and gynaecological history were associated with the constructs underlying acceptability, such as beliefs about accuracy of test results and perceived effects of testing. Our findings differ from most previous studies examining acceptability of HPV self testing in adult women. In a study of Mexican women, participants

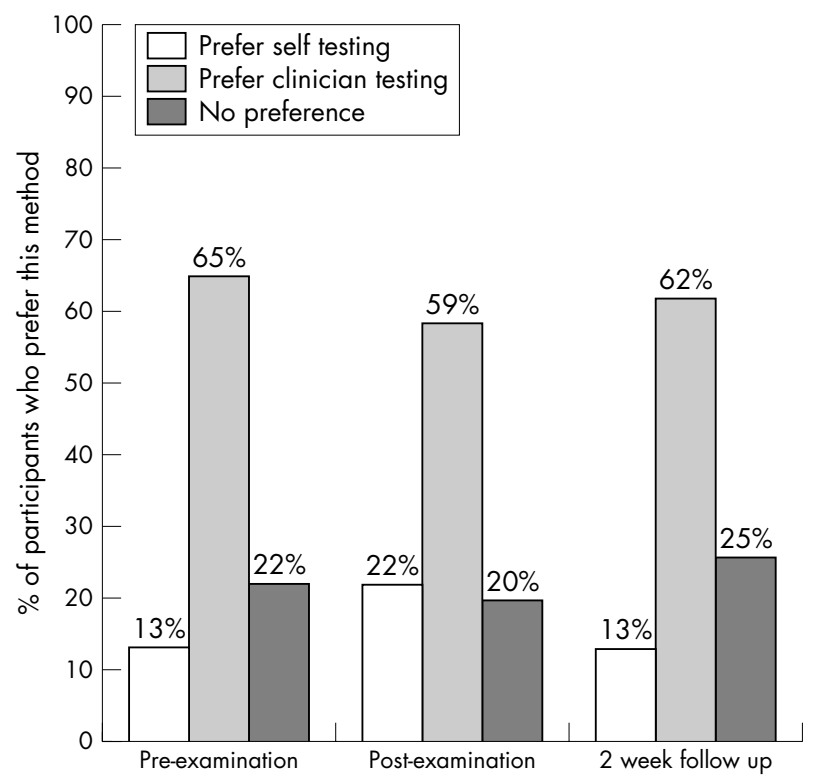

Figure 2 Preferences for type of HPV DNA testing. The bars represent the percentage of participants who preferred self testing, clinician testing, or neither at three time points: pre-examination, postexamination, and at a two week follow up visit. reported that HPV self sampling was less painful, less uncomfortable, less embarrassing, and more private than Pap testing. ${ }^{19}$ Similarly, samples of adult women at high risk for cervical dysplasia have reported self sampling to be more acceptable than clinician testing. ${ }^{17}{ }^{18}$ Harper et al found that although $94 \%$ of women presenting for colposcopy indicated that they were comfortable with HPV DNA self testing, they still wanted an annual physician visit and preferred the speculum examination if self sampling meant they could not see their physician regularly. ${ }^{14}$ In contrast with these studies, a qualitative study of attitudes about self sampling for HPV in a diverse population of women in the United Kingdom demonstrated that a large proportion of the participants, particularly those who were Indian and African-Caribbean, were concerned about performing the self test correctly. ${ }^{30}$

A number of factors may account for the differences in acceptability and preferences between adult samples and our adolescent sample. Firstly, adolescents may prefer clinician testing because they do not have as much confidence as adult women in their ability to collect specimens correctly, or because they rely more on providers to ensure that they are healthy. Secondly, our sample differed from those of the adult studies described previously in terms of sociodemographic characteristics. Participants in our study tended to have a lower income level and were more likely to be black than participants in the adult studies, and, in fact, in our study black participants reported lower self testing acceptability before the examination. Similarly, Dzuba et al reported that low income women were more likely to prefer clinician testing and Hsieh et al that white race was associated with preference for self testing. ${ }^{1931}$ Low income and/or black young women may have lower self efficacy to obtain specimens themselves, feel less empowered than other women to self screen for disease, or rely more on providers. These attitudes may be grounded in cultural beliefs or experiences of racism. ${ }^{32-34}$

Although to our knowledge there are no published studies assessing acceptability of HPV DNA self testing in adolescents, investigators have assessed adolescent acceptability of self testing for other STIs. In a study of juvenile correctional facility detainees, 39\% preferred self collection using a vaginal swab while only $8 \%$ preferred a speculum examination. $^{21}$ In a study of sexually active female adolescents, participants preferred self obtained urine testing, self 
Table 3 Multivariable linear regression models predicting pre-examination and post-examination acceptability of self testing for HPV: outcome variables include total acceptability scale scores and subscale scores

\begin{tabular}{|c|c|c|c|c|c|c|c|c|}
\hline \multirow[b]{2}{*}{$\begin{array}{l}\text { Outcome variable for each } \\
\text { model }\end{array}$} & \multicolumn{4}{|l|}{ Pre-examination } & \multicolumn{4}{|c|}{ Post-examination } \\
\hline & $\begin{array}{l}\text { Independent } \\
\text { variable }\end{array}$ & $\begin{array}{l}\beta \text { coefficient } \\
(95 \% \mathrm{Cl})^{*}\end{array}$ & $p$ Value & Model $\mathbf{R}^{2}$ & $\begin{array}{l}\text { Independent } \\
\text { variable }\end{array}$ & $\begin{array}{l}\beta \text { coefficient } \\
(95 \% \mathrm{Cl})^{*}\end{array}$ & p Value & Model $\mathbf{R}^{2}$ \\
\hline \multicolumn{9}{|l|}{$\begin{array}{l}\text { Acceptability scale score } \\
\text { Acceptability of self testing }\end{array}$} \\
\hline & $\begin{array}{l}\text { Race } \\
\text { Black }(n=15) \\
\text { White }(n=98)\end{array}$ & $\begin{array}{l}\text { Reference } \\
2.68(0.0003 \text { to } 5.37)\end{array}$ & 0.029 & 0.10 & $\begin{array}{l}\text { Race } \\
\text { Black }(n=15) \\
\text { White }(n=98)\end{array}$ & \multirow{4}{*}{$\begin{array}{l}\text { Reference } \\
0.01 \\
(-2.61 \text { to } 2.63) \\
-5.33 \\
(-0.77 \text { to }-9.89)\end{array}$} & 0.031 & 0.06 \\
\hline & Other $(n=7)$ & $\begin{array}{l}-3.74 \\
(-7.44 \text { to }-0.05)\end{array}$ & & & Other $(n=7)$ & & & \\
\hline \multicolumn{8}{|l|}{$\begin{array}{l}\text { Acceptability subscale scores } \\
\text { Trust of test result }\end{array}$} & \\
\hline & $\begin{array}{l}\text { History of STI } \\
\text { Yes }(n=81) \\
\text { No }(n=39)\end{array}$ & $\begin{array}{l}0.61 \text { (0.09 to } 1.12 \text { ) } \\
\text { Reference }\end{array}$ & 0.021 & 0.06 & & & & \\
\hline \multirow{2}{*}{ Confidence in ability to collect } & & & & & & & & \\
\hline & $\begin{array}{l}\text { Lifetime sex partners } \\
1(n=19) \\
2(n=12) \\
3-4(n=34) \\
5-6(n=26) \\
\geqslant 7(n=29)\end{array}$ & $\begin{array}{l}\text { Reference } \\
0.65(-0.72 \text { to } 2.03) \\
0.52(-0.57 \text { to } 1.61) \\
1.85 \text { (0.65 to } 3.05) \\
1.58 \text { (0.41 to } 2.77)\end{array}$ & 0.013 & 0.15 & & & & \\
\hline \multirow[t]{5}{*}{ Comfort of testing } & & & & & & \multirow{5}{*}{$\begin{array}{l}\text { Reference } \\
-1.55 \\
(-2.85 \text { to }-0.25) \\
-3.39 \\
(-5.68 \text { to }-1.09)\end{array}$} & & \\
\hline & $\begin{array}{l}\text { Used tampon in past } \\
\text { Yes }(n=69) \\
\text { No }(n=51)\end{array}$ & $\begin{array}{l}1.23(0.26 \text { to } 2.20) \\
\text { Reference }\end{array}$ & 0.019 & 0.11 & $\begin{array}{l}\text { Race } \\
\text { Black }(n=15) \\
\text { White }(n=98)\end{array}$ & & 0.009 & 0.11 \\
\hline & & & & & Other $(n=7)$ & & & \\
\hline & $\begin{array}{l}\text { History abnormal } \\
\text { Pap }\end{array}$ & & 0.035 & & & & & \\
\hline & $\begin{array}{l}\text { Yes }(n=32) \\
\text { No }(n=88)\end{array}$ & $\begin{array}{l}1.17(0.09 \text { to } 2.25) \\
\text { Reference }\end{array}$ & & & & & & \\
\hline \multirow[t]{10}{*}{ Perceived effects of testing } & & & & & & \multirow{10}{*}{$\begin{array}{l}\text { Reference } \\
-0.70 \\
(-1.73 \text { to } 0.32) \\
-1.96 \\
(-3.17 \text { to }-0.75) \\
-0.45 \\
(-1.77 \text { to } 0.87)\end{array}$} & & \\
\hline & Race & & 0.047 & 0.25 & $\begin{array}{l}\text { Sex partners/ } \\
6 \text { months }\end{array}$ & & 0.011 & 0.16 \\
\hline & $\begin{array}{l}\text { Black }(n=15) \\
\text { White }(n=98) \\
\text { Other }(n=7)\end{array}$ & $\begin{array}{l}\text { Reference } \\
8.3(0.0003 \text { to } 1.66) \\
1.56(0.22 \text { to } 2.89)\end{array}$ & & & $\begin{array}{l}0(n=9) \\
1(n=77)\end{array}$ & & & \\
\hline & & & & & & & & \\
\hline & & & & & $\geqslant 3(n=13)$ & & & \\
\hline & $\begin{array}{l}\text { Sexual partners/ } \\
6 \text { months }\end{array}$ & & 0.014 & & & & & \\
\hline & $\begin{array}{l}0(n=9) \\
1(n=77)\end{array}$ & $\begin{array}{l}\text { Reference } \\
-0.27 \\
(-1.36 \text { to } 0.82)\end{array}$ & & & & & & \\
\hline & $2(n=21)$ & $\begin{array}{l}-1.63 \\
(-2.93 \text { to }-0.33)\end{array}$ & & & & & & \\
\hline & $\geqslant 3(n=13)$ & $\begin{array}{l}-0.78 \\
(-2.21 \text { to } 0.65)\end{array}$ & & & & & & \\
\hline & $\begin{array}{l}\text { History of STI } \\
\text { Yes }(n=81) \\
\text { No }(n=39)\end{array}$ & $\begin{array}{l}0.88(0.21 \text { to } 1.54) \\
\text { Reference }\end{array}$ & 0.010 & & & & & \\
\hline
\end{tabular}

${ }^{*} \beta$ coefficient represents the mean differences in acceptability scale scores relative to reference categories for each variable. $\mathrm{Cl}$, confidence interval.

obtained vaginal testing, and clinician testing, in that order. ${ }^{22}$ However, participants were concerned that they were collecting the vaginal sample incorrectly and trusted the result of the clinician collected swab as was noted in our study. In a school based sample of adolescents, 99\% of participants reported that self collection was easy and $83 \%$ of those who had had a previous gynaecological examination preferred self testing. ${ }^{35}$ Two recent studies that enrolled adolescent and young adult women from both military and community settings also demonstrated that most women preferred self sampling. ${ }^{31} 36$

Differences between our findings and those of previous studies in adolescents are probably, in part, the result of sampling issues and differences in study design. Firstly, ours was a hospital clinic based sample, whereas participants in some of the previously described studies were recruited from school based health clinics, juvenile detention centres, and street health centres. ${ }^{21} 3536$ Patients presenting to a hospital based clinic for care may be more likely to accept clinician testing than those who do not choose to seek care in a clinic; in one study, those who attended street health centres and student health centres preferred self sampling more than those who attended STI clinics and family practices. ${ }^{36}$ In addition, we developed scales that assessed acceptability of both self and clinician testing in an identical fashion and did not present participants with any information about the possible advantages of self testing over clinician testing, possibly decreasing bias in the assessment of testing acceptability. Finally, acceptability of HPV self testing may differ from acceptability of self testing for other STIs. 
Adolescents may perceive an abnormal HPV result to be more serious than that of another STI because of its association with cancer, and therefore may be more concerned about obtaining correct test results. Testing for HPV also may be less familiar to adolescents than testing for other infections such as chlamydia, raising concerns about correct collection. Similarly, HPV infection and its link to cervical cancer are complex issues that are often poorly understood, ${ }^{37}$ which may contribute to uneasiness about self testing.

Limitations of this study include the following. Firstly, the study sample included adolescents who attended a clinic and were willing to sign up for a study of STI self testing. Acceptability may differ in those who do not choose to seek care at a clinic or are unwilling to enrol in a study of self testing. One reason for these differences may be a lack of perceived privacy in the clinical setting. Acceptability for clinician testing may also have been heightened by the procedures. Because self testing was followed by clinician testing, participants may have inferred that the investigators did not trust the result of the self collected specimen. In addition, parental consent was obtained for participants less than 18 years of age, and it is possible that those who were willing to inform parents of the study were more or less likely to find self testing acceptable. Finally, additional components of acceptability, such as clinician patient interactions, may not have been assessed by the acceptability scale, thus limiting its content validity.

Our findings have implications for adolescent STI and cervical cancer screening programmes. Both clinicians and investigators have proposed that self testing for STIs should be offered to adolescents presenting for gynaecological care. $^{21}{ }^{35}{ }^{38-40}$ If self testing for HPV is offered in the future, clinicians must recognise that some adolescents may prefer clinician to self testing, and that testing acceptability and preferences may be linked to adolescent concerns about the accuracy of self collection or associated with factors such as race, sexual experience, or gynaecological history. Clinicians should ensure that adolescents are educated about the choices available to them, and are given the opportunity to discuss any concerns and to choose the preferred testing method. ${ }^{41}{ }^{42}$ Acceptability for both self and clinician testing appears to improve after the testing experience. Thus, clinicians should explore ways of preparing adolescents so that negative anticipation is not a barrier to either type of testing. Finally, future studies of STI self testing in adolescents might explore whether acceptability is modified by educating adolescents about result accuracy and allowing them to practise the procedure.

\section{CONTRIBUTORS}

JAK conceived of the idea for this research project, obtained funding for the project (career development grant), designed the research project, supervised data collection, participated in data collection, took the lead in designing data analysis, interpreting the data, and writing the manuscript, and revised the manuscript based on suggestions from all other authors; DIB was involved in designing this specific research project and the overall research plan for JAK's career development grant, helped to interpret the results of data analysis, and critically reviewed the manuscript; SR was involved in designing this specific research project and the overall research plan for JAK's career development grant, was involved in analysing and interpreting the data, and critically reviewed the manuscript; $\mathrm{BH}$ was involved in designing the analytic plan for the research project and writing the grant that funded the project, analysed the data and provided expertise in interpreting the data, helped to write the methods section of the manuscript, and critically reviewed the manuscript; LMK was involved in designing the research protocol and data collection procedures, was involved in data collection, contributed to interpretation of data analysis, and critically reviewed the manuscript; JC contributed meaningfully to data analysis and interpretation, writing the background and discussion sections of the manuscript, and critically reviewing the manuscript; AMT was

\section{Key messages}

- The acceptability of both self and clinician testing for HPV was fairly high in a clinic based sample of female adolescents. However, acceptability was higher for clinician testing than self testing, and participants preferred clinician testing to self testing, both before and after the examination. Clinicians should recognise that some adolescents may prefer clinician to self testing and should enable them to choose the preferred method

- Acceptability of both self testing and clinician testing improved after the examination. Thus, clinicians should explore ways of preparing adolescents so that negative anticipation is not a barrier to testing

- Acceptability of self testing was linked to adolescent concerns about their ability to collect a specimen correctly. Future studies might examine whether acceptability is modified by educating adolescents about testing techniques or result accuracy or by allowing them to practise the procedure

- Race, sexual experience, and gynaecological history were associated with aspects of self testing acceptability.

involved in designing the research protocol and data collection, was primarily responsible for data collection and data entry, participated in and contributed meaningfully to data analysis and interpretation, and critically reviewed the manuscript; PAH was involved in designing this research project, provided expertise in interpretation of the analysis results, and critically reviewed the manuscript; DW was involved in designing the procedures for HPV DNA testing and writing the grant that funded the project, supervised all HPV DNA testing, helped to interpret data, and critically reviewed the manuscript; PG was involved in designing the procedures for HPV DNA testing and writing the grant that funded the project, was primarily responsible for performing HPV DNA testing, helped to interpret data, and critically reviewed the manuscript; GBS was involved in designing this specific research project and the overall research plan for JAK's career development grant, was involved in analysing and interpreting the data, and critically reviewed the manuscript.

\section{Authors' affiliations}

J A Kahn, B Huang, L M Kollar, A M Tissot, P A Hillard, G B Slap, Division of Adolescent Medicine, Cincinnati Children's Hospital Medical Center (CCHMC), Cincinnati, OH, USA

D I Bernstein, Division of Infectious Diseases, $\mathrm{CCHMC}$, Cincinnati, $\mathrm{OH}$, USA

S L Rosenthal, Division of Adolescent and Behavioral Health,

Department of Pediatrics, University of Texas at Galveston, Galveston, TX, USA

B Huang, Center for Epidemiology and Biostatistics, CCHMC,

Cincinnati, $\mathrm{OH}$, USA

J L Colyer, University of Cincinnati College of Medicine, Cincinnati, $\mathrm{OH}$, USA

D Witte, P Groen, Division of Pathology, CCHMC, Cincinnati, OH, USA A Tissot, Kent State University

Sources of funding: Dr Kahn was supported by a grant (K23 Al5092301) from the National Institutes of Health, National Institute of Allergy and Infectious Diseases.

Conflicts of interest: HPV DNA testing kits were supplied by Roche Pharmaceuticals.

\section{REFERENCES}

1 Ho GY, Bierman R, Beardsley L, et al. Natural history of cervicovaginal papillomavirus infection in young women. N Engl J Med 1998;338:423-8. 
2 Kulasingam SL, Hughes JP, Kiviat NB, et al. Evaluation of human papillomavirus testing in primary screening for cervical abnormalities: comparison of sensitivity, specificity, and frequency of referral. JAMA 2002;288: 1749-57

3 Nobbenhuis MA Walboomers JM, Helmerhorst TJ, et al. Relation of human papillomavirus status to cervical lesions and consequences for cervical-cancer screening: a prospective study. Lancet 1999;354:20-5.

4 Walboomers JM, Jacobs MV, Manos MM, et al. Human papillomavirus is a necessary cause of invasive cervical cancer worldwide. J Pathol 1999:189:12-19.

5 Nanda K, McCrory DC, Myers ER, et al. Accuracy of the Papanicolaou test in screening for and follow-up of cervical cytologic abnormalities: a systematic review. Ann Intern Med 2000;132:810-19.

$6 \mathrm{Kim} \mathrm{JJ}$, Wright TC, Goldie SJ. Cost-effectiveness of alternative triage strategies for atypical squamous cells of undetermined significance. JAMA 2002; 287:2382-90

7 Moscicki AB, Shiboski S, Broering J, et al. The natural history of human papillomavirus infection as measured by repeated DNA testing in adolescent and young women. J Pediatr 1998;132:277-84.

8 Moscicki AB, Hills NK, Shiboski S. High rate of regression of low-grade squamous intra-epithelial lesions in adolescents. Presented at the Pediatric Academic Societies Annual Meeting, Baltimore, MD, 4 May, 2002.

9 Manos MM, Kinney WK, Hurley LB, et al. Identifying women with cervical neoplasia: using human papillomavirus DNA testing for equivocal Papanicolaou results. JAMA 1999;281:1605-10.

10 Cox JT. Evaluating the role of HPV testing for women with equivocal Papanicolaou test findings. JAMA 1999;281:1645-47.

11 The ASCUS-LSIL Triage Study (ALTS) Group. Results of a randomized trial on the management of cytology interpretations of atypical squamous cells of undetermined significance. Am J Obstet Gynecol 2003;188:1383-92.

12 Wright TC, Cox JT, Massad LS, et al. 2001 Consensus guidelines for the management of women with cervical cytological abnormalities. JAMA 2002;287:2120-9.

13 Wright TC Jr, Cox JT, Massad LS, et al. 2001 Consensus guidelines for the management of women with cervical intraepithelial neoplasia. Am J Obstet Gynecol 2003; 189:295-304

14 Harper DM, Noll WW, Belloni DR, et al. Randomized clinical trial of PCRdetermined human papillomavirus detection methods: self-sampling versus clinician-directed-biologic condordance and women's preferences. Am J Obstet Gynecol 2002;186:365-73.

15 Kahn JA, Slap GB, Huang B, et al. Comparison of adolescent and young adult self-collected and clinician-collected samples for human papillomavirus. Obstet Gynecol 2004;103:952-9.

16 Dannecker C, Siebert U, Thaler CJ, et al. Primary cervical cancer screening by self-sampling of human papillomavirus DNA in internal medicine outpatient clinics. Ann Oncol 2004; 15:863-69.

17 Hillemanns P, Kimmig R, Huttemann U, et al. Screening for cervical neoplasia by self-assessment for human papillomavirus DNA. Lancet 1999:354:1970.

18 Sellors JW, Lorincz AT, Mahony JB, et al. Comparison of self-collected vaginal, vulvar and urine samples with physician-collected cervical samples for human papillomavirus testing to detect high-grade squamous intraepithelial lesions. CMAJ 2000;163:513-18.

19 Dzuba IG, Diaz EY, Allen B, et al. The acceptability of self-collected samples for HPV testing vs. the Pap test as alternatives in cervical cancer screening. Journal of Women's Health and Gender-Based Medicine 2002;1 1:265-74.

20 Smith K, Harrington K, Wingood G, et al. Self-obtained vaginal swabs for diagnosis of treatable sexually transmitted diseases in adolescent girls. Arch Pediatr Adolesc Med 2001;155:676-9.

21 Holland-Hall CM, Wiesenfeld HC, Murray PJ. Self-collected vaginal swabs for the detection of multiple sexually transmitted infections in adolescent girls. J Pediatr Adolesc Gynecol 2002; 15:307-13.
22 Serlin M, Shafer MA, Tebb K, et al. What sexually transmitted disease screening method does the adolescent prefer? Adolescents' attitudes toward first-void urine, self-collected vaginal swab, and pelvic examination. Arch Pediatr Adolesc Med 2002;156:588-91.

23 Kahn JA, Rosenthal SL, Hamann T, et al. Attitudes about human papillomavirus vaccine in young women. Int J STD AIDS 2003;14:300-6.

24 Kahn JA, Goodman E, Huang B, et al. Predictors of Papanicolaou smear return in a hospital-based adolescent and young adult clinic. Obstet Gynecol 2003;101:490-9.

25 DeVellis RF. Scale development: theory and applications. Newbury Park: Sage Publications, 1991

26 McDonald RP. Factor analysis and related methods. Hillsdale, NJ: Lawrence Erlbaum Associates, 1985

27 Marsh HW, Balla JR, McDonald RP. Goodness-of-fit indexes in confirmatory factor analysis: the effects of sample size. Psychol Bull 1988;103:305-12.

28 Bentler PM. Comparative fit indices in structural models. Psychol Bull 1990;88:588-606.

29 Browne MW, Cudeck R. Alternative ways of assessing model fit. In: Testing structural equation models. Newbury Park, CA: Sage Publications, 1993.

30 Forrest S, McCaffery K, Waller J, et al. Attitudes to self-sampling for HPV among Indian, Pakistani, African-Caribbean and white British women in Manchester, UK. J Med Screen 2004;11:85-8.

31 Hsieh YH, Howell MR, Gaydos JC, et al. Preference among female army recruits for use of self-administrated vaginal swabs or urine to screen for Chlamydia trachomatis genital infections. Sex Transm Dis 2003;30:769-73.

32 Hughes C, Lerman C, Lustbader E. Ethnic differences in risk perception among women at increased risk for breast cancer. Breast Cancer Res Treat 1996:40:25-35.

33 Paskett ED, Rushing J, D'Agostino R Jr, et al. Cancer screening behaviors of low-income women: the impact of race. Women's Health 1997;3:203-26.

34 Barroso J, McMillan S, Casey L, et al. Comparison between African-American and white women in their beliefs about breast cancer and their health locus of control. Cancer Nurs 2000;23:268-76.

35 Wiesenfeld HC, Lowry DL, Heine RP, et al. Self-collection of vaginal swabs for the detection of chlamydia, gonorrhea, and trichomoniasis: opportunity to encourage sexually transmitted disease testing among adolescents. Sex Transm Dis 2001;28:321-5

36 Richardson E, Sellors JW, Mackinnon S, et al. Prevalence of Chlamydia trachomatis infections and specimen collection preference among women, using self-collected vaginal swabs in community settings. Sex Transm Dis 2003;30:880-5.

37 Mays R, Zimet GD, Winston Y, et al. Human papillomavirus, genital warts, Pap smears, and cervical cancer: knowledge and beliefs of adolescent and adult women. Health Care Women Int 2000;21:361-74.

38 Shafer MB. Annual pelvic examination in the sexually active adolescent female: what are we doing and why are we doing it? J Adolesc Health 1998;23:68-73.

39 Blake DR, Duggan A, Quinn T, et al. Evaluation of vaginal infections in adolescent women: can it be done without a speculum? Pediatrics 1998; 102:939-44.

40 Shafer MA. With urine-based screening, do sexually active adolescent girls still need annual pelvic examinations? No: recommending annual exams is not evidence based, West J Med 2000;173:293

41 Williams GC, Cox EM, Kouides R, et al. Presenting the facts about smoking to adolescents: effects of an autonomy-supportive style. Arch Pediatr Adolesc Med 1999: 153:959-64.

42 Ryan RM, Deci EL. Self-determination theory and the facilitation of intrinsic motivation, social development, and well-being. Am Psychol 2000;55:68-78. 